\title{
Carbon and nitrogen translocation between seagrass ramets
}

\author{
Núria Marbà ${ }^{1, *}$, Marten A. Hemminga ${ }^{1}$, Miguel A. Mateo ${ }^{1}$, Carlos M. Duarte $^{2}$, \\ Yvonne E. M. Mass ${ }^{1}$, Jorge Terrados ${ }^{3}$, Esperança Gacia ${ }^{3}$ \\ ${ }^{1}$ Netherlands Institute for Ecology, Centre for Estuarine and Coastal Ecology, Korringaweg 7, 4401 NT Yerseke, \\ The Netherlands
}

${ }^{2}$ Grup d' Oceanografia Interdisciplinar, IMEDEA (CSIC-UIB) Institut Mediterrani d'Estudis Avançats, C/ Miquel Marquès 21, 07190 Esporles (Illes Balears), Spain

${ }^{3}$ Centre d'Estudis Avançats de Blanes, CSIC, Camí de Santa Bàrbara s/n, 17300 Blanes (Girona), Spain

\begin{abstract}
The spatial scale and the magnitude of carbon and nitrogen translocation was examined in 5 tropical (Cymodocea serrulata, Halophila stipulacea, Halodule uninervis, Thalassodendron ciliatum, Thalassia hemprichii) and 3 temperate (Cymodocea nodosa, Posidonia oceanica, Zostera noltii) seagrass species using ${ }^{13} \mathrm{Carbon}\left({ }^{13} \mathrm{C}\right)$ and ${ }^{15}$ Nitrogen $\left({ }^{15} \mathrm{~N}\right)$ as tracers in experiments conducted in situ. Seagrass leaf and rhizome production during the study period varied from $<0.001$ to $0.015 \mathrm{~g} \mathrm{DW}$ shoot ${ }^{-1} \mathrm{~d}^{-1}$ and 0.002 to $0.017 \mathrm{~g} \mathrm{DW}$ rhizome ape ${ }^{-1} \mathrm{~d}^{-1}$, respectively. Based on measured leaf and rhizome growth rates, the demand of resources for leaf production varied from 0.19 to $4.99 \mathrm{mgC} \mathrm{shoot}^{-1} \mathrm{~d}^{-1}$, and from 0.01 to $0.24 \mathrm{mgN}$ shoot $^{-1} \mathrm{~d}^{-1}$, while the demand for rhizome production varied from 0.62 to $5.57 \mathrm{mgC}$ rhizome apex ${ }^{-1} \mathrm{~d}^{-1}$ and from 0.02 to $0.12 \mathrm{mgN}$ rhizome apex ${ }^{-1} \mathrm{~d}^{-1}$. Seagrass leaves incorporated the isotopes at rates ranging from 0.04 to $0.63 \mu \mathrm{g}^{13} \mathrm{C} \mathrm{g} \mathrm{DW}^{-1} \mathrm{~h}^{-1}$, and $<0.01$ to $0.35 \mu \mathrm{g}^{15} \mathrm{~N} \mathrm{~g}$ $\mathrm{DW}^{-1} \mathrm{~h}^{-1}$. After $4 \mathrm{~d}$, all incubated shoots had shared part of the incorporated ${ }^{13} \mathrm{C}$ and ${ }^{15} \mathrm{~N}$ with ramets placed at maximum distances ranging from 2.7 (H. stipulacea) to $81 \mathrm{~cm}$ (C. nodosa), indicating that seagrass clonal integration may be maintained between $1.6 \mathrm{~d}$ (H. stipulacea) and $5.4 \mathrm{yr}$ (P. oceanica). Resource translocation within seagrass clones was stimulated towards horizontal rhizome apices. Seagrass ramets, in $4 \mathrm{~d}$, shared with their neighbours between 0.37 and $390 \mu \mathrm{g}^{13} \mathrm{C}$ and between 0.02 and $178 \mu \mathrm{g}^{15} \mathrm{~N}$. During the study period, resource translocation would supply $<5 \%$ and up to $40 \%$ of the leaf carbon and nitrogen required by a neighbouring developing ramet, respectively, and $<5 \%$ and up to $36 \%$ of the carbon and nitrogen required for rhizome growth; provided that the incorporated resources over $1 \mathrm{~d}$ were mobilised at similar rates over $4 \mathrm{~d}$. These results conclusively demonstrate physiological integration between seagrass ramets, and that resource translocation may be an important mechanism for young seagrass ramets to acquire resources and for seagrass clones to expand and persist.
\end{abstract}

KEY WORDS: Carbon $\cdot$ Nitrogen $\cdot$ Translocation $\cdot$ Seagrass

\section{INTRODUCTION}

Seagrasses grow by iterating modular units (ramets) that often remain interconnected by pieces of rhizome. This form of construction may maintain the ramets phys-

\footnotetext{
*Present address: Grupo de Oceanografía Interdisciplinar, IMEDEA (CSIC-UIB) Institut Mediterrani d'Estudis Avançats, C/ Miquel Marquès 21, 07190 Esporles (Illes Balears), Spain. E-mail: ieanmb@clust.uib.es
}

iologically connected, allowing resource translocation from neighbouring ramets to affect their growth and survival, as occurs in many terrestrial clonal plants (e.g. Jónsdóttir \& Callaghan 1990, Alpert 1991, Evans 1991, 1992, Avice et al. 1996). Resource translocation, therefore, may be an important mechanism for the internal redistribution of resources within seagrass clones, thereby enhancing their expansion and persistence. There is, however, a striking paucity of information on the capacity of resource sharing between seagrass ramets. 
Seagrasses often develop extensive meadows in nutrient-poor environments, where their growth is nutrient limited (e.g. Short et al. 1985, Powell et al. 1989, Perez et al. 1990). Seagrasses acquire nutrients by leaves and roots from the water column and sediment porewater, respectively (e.g. Stapel et al. 1996, Pedersen et al. 1997, Terrados \& Williams 1997, Lee \& Dunton 1999). Carbon fixation and nutrient uptake by individual ramets does not always fulfil their resource demand, and the existence of internal resource transport between seagrass ramets has been suggested, supported by evidence that the ramets of some seagrass species are physiologically integrated. For instance, leaf growth of Thalassia testudinum shaded ramets is similar to that of connected unshaded ramets, but it decreases when rhizome connections are cut (Tomasko \& Dawes 1989). Similarly, young ramet and rhizome growth are greatly reduced when the horizontal rhizome of Cymodocea nodosa is severed (Terrados et al. 1997b). Laboratory and in situ experiments using radiocarbon demonstrated that carbon was indeed mobilised within Zostera americana and Posidonia oceanica clones (Harrison 1978, Libes \& Boudouresque 1987) and transferred from leaves to rhizomes and roots in T. testudinum (Bittaker \& Iverson 1976). The use of ${ }^{15} \mathrm{~N}$ revealed that nitrogen taken up by old leaves is translocated to new leaves in $Z$. marina shoots (Pedersen \& Borum 1992). Despite the evidence that resource mobilisation across seagrass parts occurs, the magnitude and the spatial scale of resource translocation between neighbouring seagrass ramets remain largely unknown (but see Libes \& Boudouresque 1987 , Terrados et al. 1997b).

Here, we examined the patterns (e.g. rates, range) of resource translocation in 5 tropical (Cymodocea serrulata, Halophila stipulacea, Halodule uninervis, Thalassodendron ciliatum, Thalassia hemprichii) and 3 temperate (Cymodocea nodosa, Posidonia oceanica, Zostera noltii) seagrass species using ${ }^{13} \mathrm{C}$ and ${ }^{15} \mathrm{~N}$ as tracers in in situ experiments. In addition, we estimated the contribution of translocated carbon and nitrogen to satisfy the resource demand of neighbour ramets and horizontal rhizomes during the study period.

\section{MATERIALS AND METHODS}

We examined ${ }^{13} \mathrm{C}$ and ${ }^{15} \mathrm{~N}$ translocation in Cymodocea serrulata, Halophila stipulacea, Halodule uninervis, Thalassodendron ciliatum, and Thalassia hemprichii in March 1997 in a tropical mixed seagrass bed developed on a gently sloping calcareous substrate at Nyali Beach (Kenya, $4^{\circ} 0.1^{\prime} \mathrm{S}, 39^{\circ} 42.5^{\prime} \mathrm{E}$ ). This seagrass meadow, composed of a mosaic of patches of the species tested, extended from the shore to the inner part of the reef lagoon, and it experienced tides with 2 to $4 \mathrm{~m}$ amplitude. Hence, most of the $100 \mathrm{~m}$ wide belt of the seagrass bed close to the beach remained exposed to air for a few hours during low tide, except for seagrass patches colonising shallow, permanently flooded pools. These permanently submerged seagrass patches provided the experimental plant material at this site. The waters at Nyali Beach during high tide were turbid and contained 1 to $3 \mu \mathrm{M} \mathrm{NH}$ and 1 to $2 \mu \mathrm{M} \mathrm{NO}_{2}+\mathrm{NO}_{3}$ (J. Kazungu unpubl. data). Dissolved inorganic nitrogen (DIN) concentration in sediment porewater was high (200 to $800 \mu \mathrm{M} \mathrm{NH} \mathrm{NH}_{4}$ and 15 to $50 \mu \mathrm{M} \mathrm{NO}_{2}+\mathrm{NO}_{3 i}$ J. Kazungu unpubl. data).

Cymodocea nodosa and Posidonia oceanica grew in monospecific and patchy Mediterranean seagrass beds

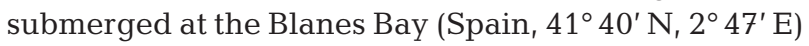
and Fenals Point (Spain, 41 $41^{\circ} \mathrm{N}, 2^{\circ} 52^{\prime} \mathrm{E}$ ), respectively. The C. nodosa meadow extended from 9 to $>20 \mathrm{~m}$ depth, whereas that of $P$. oceanica covered coarser sediment at water depths from 13 to $20 \mathrm{~m}$. Experimental plants of $C$. nodosa and $P$. oceanica were selected at 11 and $15 \mathrm{~m}$ depth, respectively, where they received, at the time when the experiments were performed

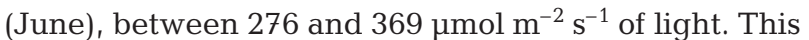
corresponds to about $20 \%$ of surface irradiance (E.C. \& C.M.D. unpubl. data). Water column DIN concentrations were $0.07 \mu \mathrm{M} \mathrm{NH}_{4}$ and $0.5 \mu \mathrm{M} \mathrm{NO}_{2}+\mathrm{NO}_{3}$, and DIN in sediment porewater nitrogen, present as $\mathrm{NH}_{4}$, averaged $104 \mu \mathrm{M} \mathrm{NH}_{4}$ (C.M.D. unpubl. data).

Zostera noltii occurred as a patchy meadow on a muddy tidal flat at Kattendijke (The Netherlands, $51^{\circ} 31.8^{\prime} \mathrm{N}, 3^{\circ} 56.2^{\prime} \mathrm{E}$ ). The amplitude of tidal fluctuations at Kattendijke ranges from 2 to $4 \mathrm{~m}$. Z. noltii, in July (i.e. the time when the experiments were conducted), rooted into sediment with porewater DIN concentrations of 50 to $150 \mu \mathrm{M} \mathrm{NH}_{4}$ and 5 to $10 \mu \mathrm{M} \mathrm{NO}_{2}+$ $\mathrm{NO}_{3}$. Its leaves were submerged into water with DIN concentrations ranging between 1 and $15 \mu \mathrm{M} \mathrm{NH}_{4}$ and between 0 and $10 \mu \mathrm{M} \mathrm{NO} \mathrm{NO}_{2}$.

The experiments were performed within the period of the fastest clonal growth of the species (Vermaat et al. 1995, Marbà et al. 1996, Vermaat \& Verhagen 1996), thus when the demand for resources from developing ramets was highest. At each site from the edges of patches of each studied species, we collected 3 long horizontal rhizomes, containing the rhizome apex, short shoots and roots. On these rhizomes, we checked the average position of the youngest fully developed shoot. We then selected 7 intact long horizontal rhizomes growing at the edges of seagrass patches to be used for the in situ experiments. The incubations were performed during sunny days, starting late in the morning or noon. We placed a plastic bag, sealed at its base, enclosing the leaves of the youngest fully developed shoot on each selected horizontal rhizome. Leak- 
age from the bags was not detected when in the laboratory seagrass shoots were enclosed following the same experimental set-up as in the field and injected ink. The plastic bags had a septum with a stopper for injection, and an outlet to connect a pump to empty the incubation solution at the end of the incubation period. We used plastic bags of different volumes for each species (Table 1) to account for the large differences in shoot size amongst them. We filled the bag with seawater, and then injected a solution containing $\mathrm{NaH}^{13} \mathrm{CO}_{3}$ and ${ }^{15} \mathrm{NH}_{4} \mathrm{Cl}$ to achieve a final concentration of $235 \mu \mathrm{mol}$ $\mathrm{NaH}^{13} \mathrm{CO}_{3}$ and $40 \mu \mathrm{mol}{ }^{15} \mathrm{NH}_{4} \mathrm{Cl}$. Therefore, ${ }^{13} \mathrm{C}$ was added into the incubation bags at tracer concentration (total dissolved inorganic carbon in seawater,

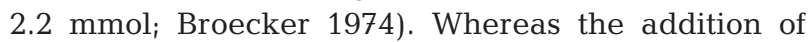
${ }^{15} \mathrm{NH}_{4} \mathrm{Cl}$ increased the ambient ammonium concentration during the incubations considerably, particularly in the experiments performed in the Mediterranean Sea. These experiments were designed to study the capacity of seagrass clones to mobilise their internal resources, and thus it was required that incubated leaves incorporated enough tracer to enrich the tissues of neighbour ramets at measurable concentrations. Because the low leaf incorporation rate of nitrogen, compared with that of carbon, and the fact that ammonium uptake rate strongly depends on ammonium ambient concentration (e.g. Stapel et al. 1996, Terrados \& Williams 1997, Lee \& Dunton 1999), we decided to provide labelled ammonium at high ambient concentration to ensure the success of the experiments. The amount of isotope added in the water column indicates that the amount of ${ }^{13} \mathrm{C}$ incorporated into the ramet should be just a fraction of the total carbon taken up during the incubation, whereas most of the ammonium taken up by the ramet should be of the labelled form.

About 2 to $2.5 \mathrm{~h}$ after the incubation was initiated, we transferred the water with the aid of a pump from the incubation bags to empty sealed plastic bags, to prevent loss of remaining ${ }^{13} \mathrm{C}$ and ${ }^{15} \mathrm{~N}$ from the incubation water to the environment during the removal of the incubation bags. Subsequently, the incubation plastic bags were removed, and the leaf sheaths of the incubated shoots were punched with a needle for growth determinations. Four days later, we retrieved the long rhizome pieces containing the rhizome apex, incubated shoot, and as many connected ramets as possible. The rhizomes were carefully transported to the laboratory, where distance between connected ramets, rhizome diameter, shoot age, leaf elongation on punched shoots during the marking period, and the position of each ramet along the rhizomes were recorded. These measurements provided characterisation of plant architecture, and estimates of plant growth.

Subsequently, we cut the rhizomes into segments, each containing 1 ramet, separated the leaves from rhizome and roots, and measured, after overnight desiccation at $60^{\circ} \mathrm{C}$, their mass. These samples were ground to a fine powder, and the carbon and nitrogen content in plant tissues were analysed in 7 rhizomes of each species using a Carlo-Erba Element Analyzer. The ${ }^{13} \mathrm{C}$ signature was measured in all ramets of 4 experimental rhizomes, and ${ }^{15} \mathrm{~N}$ in all ramets of 3 experimental rhizomes. Natural abundance of ${ }^{13} \mathrm{C}$ in plant tissues was measured for leaf shoots and below-ground modules (i.e. rhizomes and roots) of all ramets of the 3 rhizomes harvested without incubation with tracers. The natural abundance of ${ }^{15} \mathrm{~N}$ was measured in leaves and below-ground modules of only 4 ramets of unmanipulated rhizomes, as between ramet variability was negligible when compared with the isotopic variability among neighbouring ramets following incubation. The carbon and nitrogen isotopic composition of the plant material was determined using a Finnigan Delta S mass spectrometer, following on-line combustion of the organic matter in a Carlo-Erba Element Analyzer.

The carbon and nitrogen demand, the amount of ${ }^{13} \mathrm{C}$ and ${ }^{15} \mathrm{~N}$ incorporated during the incubation time, the amount of ${ }^{13} \mathrm{C}$ and ${ }^{15} \mathrm{~N}$ exported to neighbouring ramets over $4 \mathrm{~d}$, and the spatial distribution of isotope mobilisation within seagrass rhizomes were calculated. The relative abundance of the stable heavy isotopes ${ }^{13} \mathrm{C}$ and ${ }^{15} \mathrm{~N}$ was expressed in the $\delta$ notation, calculated as the deviation, in parts per thousand (\%), the difference between the isotope content of the sample of the sample $\left(R_{\mathrm{sa}}\right)$ and that of the standard $\left(R_{\mathrm{std}}\right)$, using the equation,

$$
\delta \text { stable isotope }(\%)=\frac{R_{\mathrm{sa}} \pm R_{\mathrm{std}}}{R_{\mathrm{std}}} \times 1000
$$

$\delta^{13} \mathrm{C}$ was expressed relative to a calcium carbonate standard, PDB $\left(R_{\mathrm{pdb}}=0.0112372\right)$, and $\delta^{15} \mathrm{~N}$ relative to atmospheric nitrogen $\left(R_{\text {atmospheric nitrogen }}=0.003665\right)$. 
The rate of leaf appearance on shoots of the studied seagrass species during the experimental period was calculated as the average number of new leaves on the marked shoots, identified as those young leaves without a mark, divided by the duration of the marking period (i.e. 4 d). The time elapsed between production of 2 consecutive leaves on a shoot (i.e. the leaf plastochron interval) was estimated as the inverse of the leaf appearance rate. None of the shoots of Cymodocea nodosa marked, however, produced a new leaf during the experimental period. The estimates of leaf plastochron interval for C. nodosa used here were measured at the experimental meadow in June 1998 (i.e. during the same seasonal period but $1 \mathrm{yr}$ after the experiments were conducted). Leaf elongation rate was calculated as the length of new leaves plus the elongation of punched leaves on the marked shoots divided by the duration of the marking period (i.e. $4 \mathrm{~d}$ ). Leaf elongation rate was converted into net increase in leaf mass per shoot (i.e. leaf production) by multiplying leaf elongation rate (i.e. $\mathrm{cm} \mathrm{d}^{-1}$ ) by the specific leaf mass (i.e. $\mathrm{gDW} \mathrm{cm}^{-1}$ ).

Seagrass rhizome production of all species, except Halophila stipulacea, was assessed using seagrass reconstructing techniques, based on the shoot age gradient along the horizontal rhizome (Duarte et al. 1994). The age of the shoots attached to each harvested horizontal rhizome was estimated as the number of leaf scars on vertical rhizomes plus the number of standing leaves multiplied by the leaf plastochrone interval. The rate of appearance of horizontal rhizome internodes was calculated by regressing the number of internodes in between 2 consecutive shoots connected along a horizontal rhizome against the age difference of the shoots. The regression slope represented the average number of horizontal rhizome internodes produced in the time required for a shoot to produce a new leaf. Horizontal rhizome internode appearance rate was converted into horizontal rhizome production by multiplying this slope, using the leaf plastochrone interval to convert it into chronological time (i.e. d), by the average mass of a horizontal rhizome internode. Rhizome production of $H$. stipulacea was measured by tagging 5 rhizome apices of this species, and quantifying, $4 \mathrm{~d}$ later, the number and length of the rhizome internodes produced during the marking period.

Leaf carbon and nitrogen demand for 1 ramet was estimated by multiplying the leaf production per shoot by the average leaf carbon and nitrogen concentration. Similarly, the demand of carbon and nitrogen for horizontal rhizome production was calculated by multiplying horizontal rhizome production by the average carbon and nitrogen concentration of the rhizomes.

The excess of ${ }^{13} \mathrm{C}$ and ${ }^{15} \mathrm{~N}$ mass in leaves and belowground modules of each ramet attached to the experi- mental rhizomes was estimated according to Bouton (1991). The amount of ${ }^{13} \mathrm{C}$ and ${ }^{15} \mathrm{~N}$ incorporated by the incubated shoots during the incubation period was calculated as the sum of the excess tracer isotopic mass measured $4 \mathrm{~d}$ after the incubation in each ramet connected to the experimental rhizomes. The amount of ${ }^{13} \mathrm{C}$ and ${ }^{15} \mathrm{~N}$ exported to neighbouring ramets was estimated as the total amount of ${ }^{13} \mathrm{C}$ and ${ }^{15} \mathrm{~N}$ incorporation minus the excess of isotopic mass remaining in the incubated ramet $4 \mathrm{~d}$ after the incubation.

Most horizontal rhizomes of Halophila stipulacea and Zostera noltii, and some of Halodule uninervis, Cymodocea serrulata, C. rotundata and Thalassodendron ciliatum presented short branches with a median of 2 (range between 1 to 4 ) ramets branch ${ }^{-1}$. Each whole short branch, together with its ramets, was considered as 1 'ramet' on the main horizontal rhizome axis with position equal to that where it was inserted. We examined the existence of a gradient in nitrogen content in leaves, rhizomes and roots along the rhizomes of the different species by averaging the nitrogen concentration in the leaves, rhizome and roots in ramets placed at similar positions relative to the horizontal rhizome apex. The significance of the increase in tissue (i.e. leaves, rhizomes, roots) $\mathrm{N}$ concentration as seagrass ramets approached the rhizome apex was statistically tested using least-squares regression analysis between tissue $\mathrm{N}$ concentration and ramet position for each species studied. The amount of variability in module mass occurring across and within species was described by their coefficient of variation. Paired $t$-test was used to statistically test the existence of asymmetry in translocation of isotopes towards younger and older neighbour ramets in each species investigated, and Wilcoxon's signed-ranks test was used to test whether asymmetric transport of resources was a common phenomena across the seagrass species studied.

\section{RESULTS}

\section{Ramet mass and growth}

The mass of seagrass modules (i.e. shoots, rhizome, and roots) varied over 3 orders of magnitude among the plants studied (Fig. 1). The largest variability in module mass occurred across species (coefficient of variation, $\mathrm{CV}_{\text {shoot }}=188 \%, \mathrm{CV}_{\text {rhizome }}=164 \%, \mathrm{CV}_{\text {roots }}=$ $194 \%)$, Zostera noltii being the smallest and Posidonia oceanica the largest seagrass species amongst those examined. Module mass also exhibited substantial changes within rhizomes of similar species (average coefficient of variation, $\mathrm{CV}_{\text {shoot }}=52 \%, \mathrm{CV}_{\text {rhizome }}=$ $43.2 \%, \mathrm{CV}_{\text {roots }}=57.7 \%$ ), because new ramets only achieve a full development once the horizontal rhi- 
zome has grown an additional 4 to 12 internodes, depending on plant species, following the birth of the new ramet (Fig. 1). Neighbouring ramets were spaced between 2.4 and $6.2 \mathrm{~cm}$ along the rhizomes, and rhizome diameters ranged from 1.98 to $11.56 \mathrm{~mm}$ across species (Table 2). Seagrass leaves accounted for most

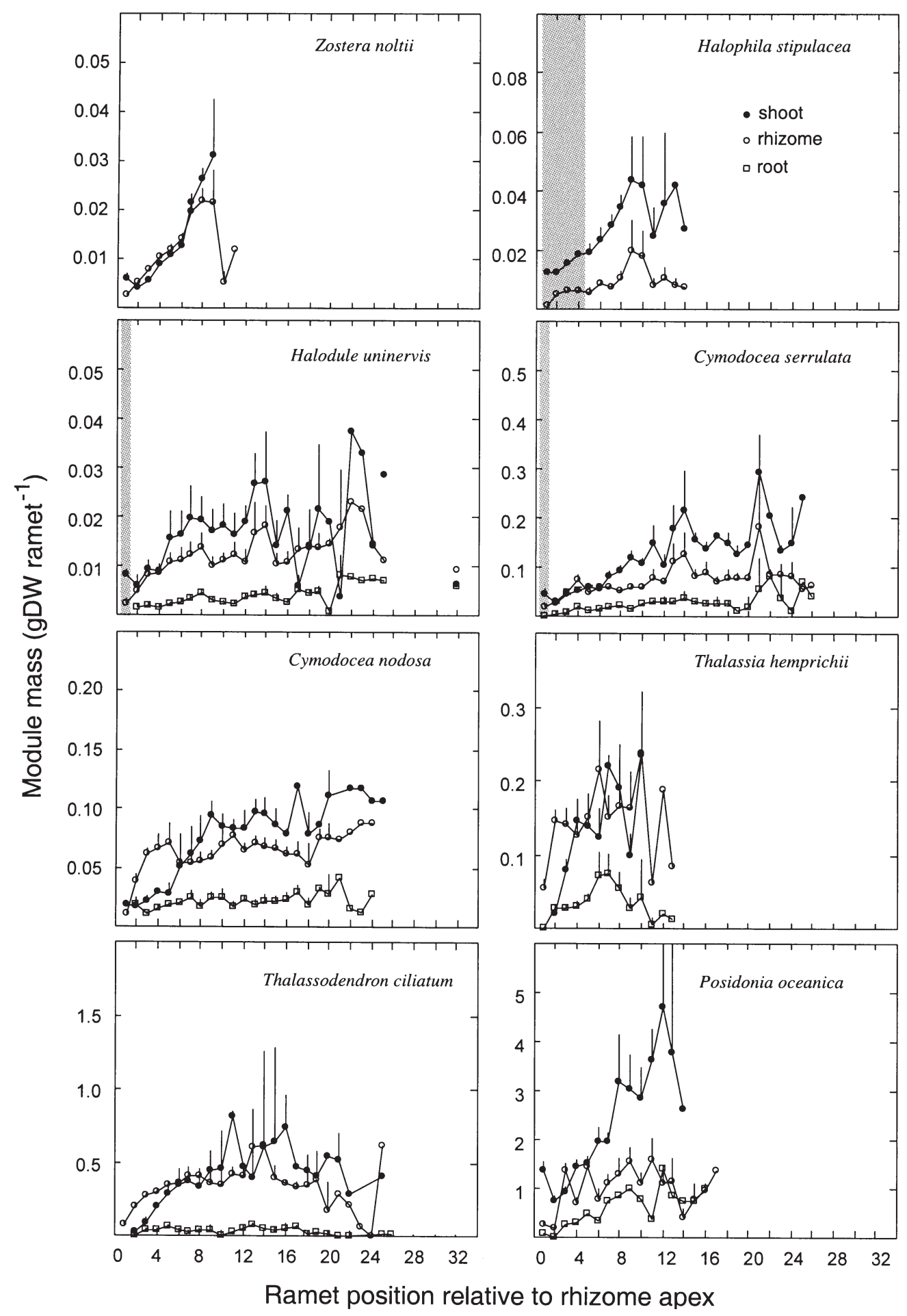

Fig. 1. Average mass of the modules (leaves, rhizome, roots) of seagrass ramets along the experimental rhizome fragments. Only half standard error bars are shown. The grey areas of the plot indicate the new ramets produced during the experimental period (i.e. 4 d) 
Table 2. Average $\pm \mathrm{SE}$, where available, for the rhizome diameter, spacing between neighbouring shoots, shoot mass, leaf production, rhizome production, and rhizome elongation rate

\begin{tabular}{|c|c|c|c|c|c|c|}
\hline Species & $\begin{array}{l}\text { Rhizome } \\
\text { diameter } \\
(\mathrm{mm})\end{array}$ & $\begin{array}{c}\text { Distance } \\
\text { between } \\
\text { neighbouring } \\
\text { shoots }(\mathrm{cm})\end{array}$ & $\begin{array}{l}\text { Shoot mass } \\
\qquad(g \mathrm{DW})\end{array}$ & $\begin{array}{l}\text { Leaf production } \\
\left(\mathrm{g} \text { DW shoot }{ }^{-1} \mathrm{~d}^{-1}\right)\end{array}$ & $\begin{array}{c}\text { Rhizome } \\
\text { production } \\
(\mathrm{g} \mathrm{DW} \text { rhizome } \\
\left.\text { apex }^{-1} \mathrm{~d}^{-1}\right)\end{array}$ & $\begin{array}{l}\text { Rhizome } \\
\text { elongation } \\
\text { rate }(\mathrm{cm} \\
\left.\text { apex }^{-1} \mathrm{~d}^{-1}\right)\end{array}$ \\
\hline Cymodocea nodosa & $3.98 \pm 0.12$ & $5.26 \pm 0.18$ & $0.118 \pm 0.017$ & $0.0023 \pm 0.0005$ & 0.0063 & 0.53 \\
\hline Cymodocea serrulata & $3.96 \pm 0.24$ & $4.03 \pm 0.10$ & $0.188 \pm 0.042$ & $0.0068 \pm 0.0008$ & 0.0169 & 1.29 \\
\hline Halophila stipulacea & $1.99 \pm 0.03$ & $2.56 \pm 0.17$ & $0.019 \pm 0.003$ & $0.0108 \pm 0.0010$ & 0.0082 & 2.70 \\
\hline Halodule uninervis & $1.98 \pm 0.12$ & $2.42 \pm 0.07$ & $0.019 \pm 0.005$ & $0.0023 \pm 0.0008$ & 0.0020 & 0.61 \\
\hline Posidonia oceanica & $11.56 \pm 1.19$ & $2.44 \pm 0.20$ & $2.496 \pm 0.501$ & $0.0152 \pm 0.0016$ & 0.0048 & 0.01 \\
\hline Thalassodendron ciliatum & $5.84 \pm 0.18$ & $4.00 \pm 0.11$ & $0.570 \pm 0.149$ & $0.0136 \pm 0.0019$ & 0.0041 & 0.05 \\
\hline Thalassia hemprichii & $3.94 \pm 0.12$ & $6.22 \pm 0.35$ & $0.176 \pm 0.044$ & $0.0069 \pm 0.0036$ & 0.0039 & 0.21 \\
\hline Zostera noltii & $1.98 \pm 0.06$ & $2.67 \pm 0.10$ & $0.008 \pm 0.001$ & $0.0005 \pm 0.0001$ & 0.0041 & 0.43 \\
\hline
\end{tabular}

of the ramet mass, except in Thalassia hemprichii and young ramets of Cymodocea nodosa, Thalassodendron ciliatum and $P$. oceanica, in which rhizomes were the dominant components of the ramet in mass (Fig. 1). The experimental seagrass rhizomes elongated at rates ranging from 0.01 to $2.7 \mathrm{~cm} \mathrm{apex}^{-1} \mathrm{~d}^{-1}$ (Table 2). Most seagrass rhizomes, therefore, did not produce any new shoots during the experiment. Only the horizontal rhizomes of $C$. serrulata and Halodule uninervis produced, on average, 1 new ramet, and those of Halophila stipulacea 4, during the study period (Fig. 1). Leaf and rhizome production ranged between $<0.001$ and $0.015 \mathrm{gDW}_{\text {shoot }}{ }^{-1} \mathrm{~d}^{-1}$ and 0.002 to $0.017 \mathrm{~g} \mathrm{DW}$ rhizome apex ${ }^{-1} \mathrm{~d}^{-1}$, respectively, across species (Table 2).

\section{Nitrogen concentration and demands}

Nitrogen concentration in seagrass leaves varied between 0.97 and $3.51 \%$ DW (Fig. 2), often being below the median concentration typically observed in seagrass leaves (i.e. $2 \%$ DW, cf. Duarte 1990). The nitrogen concentration in seagrass rhizomes and roots was, on average, about $1 / 2$ and $1 / 3$, respectively, of leaf nitrogen concentration (Fig. 2). In addition, the nitrogen concentration of seagrass modules showed important variability across the interconnected ramets (Fig. 2), with the $\mathrm{N}$ concentration increasing as ramets approached the rhizome apex (i.e. from older to younger shoots). The nitrogen concentration in the rhizomes and roots of all seagrass species, except in Posidonia oceanica rhizomes and Thalassia hemprichii rhizomes and roots, significantly increased towards rhizome apex (regression analysis, $\mathrm{p}<0.05$ ), this gradient being strongest in rhizomes of Cymodocea nodosa, Cymodocea serrulata and Zostera noltii (Fig. 2). Moreover, the leaf $\mathrm{N}$ concentration of Halodule uninervis, $C$. nodosa, C. serrulata and Zostera noltii also significantly increased towards younger shoots (regression analysis, $\mathrm{p}<0.05$ ), although this gradient was less steep than that observed for below-ground modules (Fig. 2). The C:N ratio in seagrass leaves varied from 13.4 to 30 , that in seagrass rhizomes from 25.3 to 103.1 , and that in seagrass roots from 33.2 to 110.6 (Table 3 ). The C:N ratio increased from younger to older ramets

Table 3. Average \pm SE of the C:N ratio in leaves, rhizomes and roots, and average carbon and nitrogen demand of shoots and horizontal rhizomes of the seagrasses studied

\begin{tabular}{|c|c|c|c|c|c|c|c|}
\hline \multirow[t]{2}{*}{ Species } & \multicolumn{3}{|c|}{$\mathrm{C}: \mathrm{N}$ ratio } & \multicolumn{2}{|c|}{$\begin{array}{l}\text { Carbon demand } \\
\left(\mathrm{mg} \mathrm{C} \mathrm{d}^{-1}\right)\end{array}$} & \multicolumn{2}{|c|}{$\begin{array}{l}\text { Nitrogen demand } \\
\left(\mathrm{mg} \mathrm{N} \mathrm{d}^{-1}\right)\end{array}$} \\
\hline & Shoot & Rhizome & Root & Shoot & Rhizome apex & Shoot & Rhizome apex \\
\hline Cymodocea nodosa & $17.13 \pm 0.31$ & $36.26 \pm 2.12$ & $34.52 \pm 1.48$ & 0.75 & 1.95 & 0.05 & 0.08 \\
\hline Cymodocea serrulata & $22.18 \pm 0.31$ & $85.08 \pm 4.79$ & $44.06 \pm 1.37$ & 2.07 & 5.57 & 0.11 & 0.12 \\
\hline Halophila stipulacea & $16.76 \pm 0.45$ & $38.38 \pm 2.08^{a}$ & & 0.61 & 1.92 & 0.04 & 0.07 \\
\hline Halodule uninervis & $20.69 \pm 0.73$ & $40.77 \pm 1.95^{\mathrm{a}}$ & & 0.78 & 0.62 & 0.04 & 0.02 \\
\hline Posidonia oceanica & $27.08 \pm 0.43$ & $53.24 \pm 2.41$ & $110.65 \pm 6.16$ & 4.99 & 1.89 & 0.21 & 0.05 \\
\hline Thalassodendron ciliatum & $30.44 \pm 0.81$ & $103.11 \pm 6.07$ & $91.08 \pm 6.05$ & 4.30 & 1.61 & 0.17 & 0.02 \\
\hline Thalassia hemprichii & $13.84 \pm 0.36$ & $33.24 \pm 2.67$ & $33.27 \pm 1.41$ & 2.88 & 1.41 & 0.24 & 0.06 \\
\hline Zostera noltii & $13.40 \pm 0.20$ & $25.37 \pm 1.25^{\mathrm{a}}$ & & 0.19 & 1.04 & 0.01 & 0.05 \\
\hline
\end{tabular}




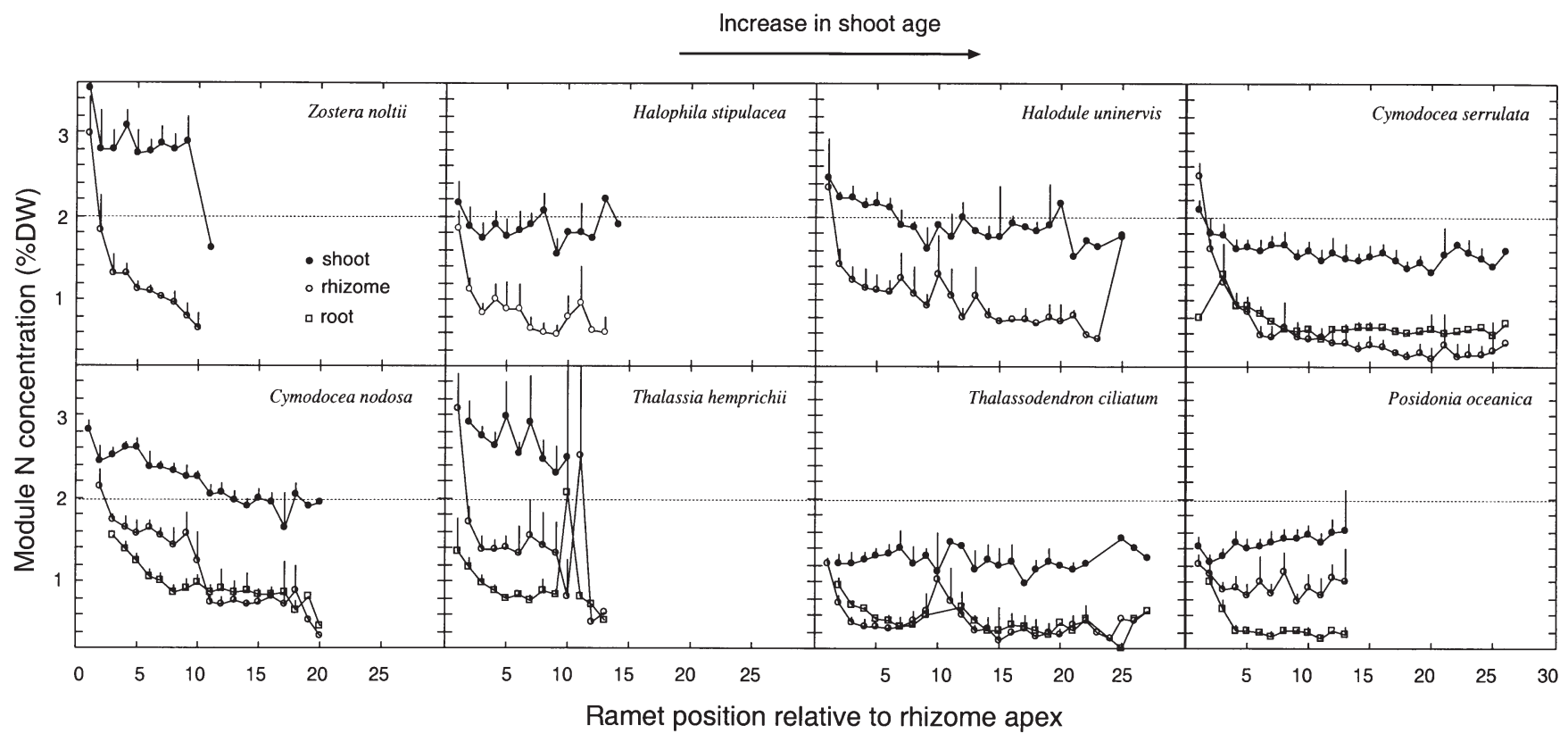

Fig. 2. Average leaf, rhizome, and root nitrogen content in the ramets attached to the seagrass rhizomes studied. Only half standard error bars are shown. Dashed lines indicate the median nitrogen content of seagrass leaves: lower nitrogen concentration than the critical level may reflect nutrient limitation (Duarte 1990)

in those species exhibiting a gradient in tissue nitrogen concentration with ramet age (data not shown).

The large variability in nitrogen concentration in plant tissues together with that in growth rates yielded large differences in carbon and nitrogen demand among seagrass species (Table 3). The carbon and nitrogen demand for leaf growth varied from 0.19 to $4.99 \mathrm{mg} \mathrm{C}$ shoot $^{-1} \mathrm{~d}^{-1}$ and 0.01 to $0.24 \mathrm{mgN}$ shoot $^{-1} \mathrm{~d}^{-1}$ (Table 3). Similarly, the resource demand for rhizome growth varied from 0.62 to $5.57 \mathrm{mgC}$ rhizome apex ${ }^{-1}$ $\mathrm{d}^{-1}$ and from 0.02 to $0.12 \mathrm{mgN}$ rhizome apex ${ }^{-1} \mathrm{~d}^{-1}$ among the examined species (Table 3 ).

\section{${ }^{13} \mathrm{C}$ and ${ }^{15} \mathrm{~N}$ incorporation and translocation}

At the end of the experiment (i.e. $4 \mathrm{~d}$ after shoot incubation), experimental rhizomes were enriched up to $231 \%$ ${ }^{13} \mathrm{C}$ and up to $3271 \%{ }^{15} \mathrm{~N}$ relative to natural isotopic abundance (Table 4). However, 1 experimental rhizome of Halodule uninervis was not ${ }^{13} \mathrm{C}$ or ${ }^{15} \mathrm{~N}$ enriched, and 2 rhizomes of Halophila stipulacea presented ${ }^{15} \mathrm{~N}$ enrichment $<60 \%$. $\delta^{13} \mathrm{C}$ and $\delta^{15} \mathrm{~N}$ values in the modules of the experimental rhizomes revealed that seagrass leaves incorporated between 1.7 and $824 \mu \mathrm{g}^{13} \mathrm{C} \mathrm{shoot}^{-1}$ and between 0.021 and $919 \mu \mathrm{g}^{15} \mathrm{~N}_{\text {shoot }}{ }^{-1}$ during the incubation period (Figs $3 \& 4$ ). The amounts of ${ }^{13} \mathrm{C}$ and ${ }^{15} \mathrm{~N}$ incorporated by seagrass leaves represented ${ }^{13} \mathrm{C}$ and ${ }^{15} \mathrm{~N}$ net uptake rates ranging from 0.04 to $0.63 \mu \mathrm{g}^{13} \mathrm{C} \mathrm{gDW}^{-1} \mathrm{~h}^{-1}$ and between $<0.01$ and $0.35 \mu g^{15} \mathrm{NgDW}^{-1} \mathrm{~h}^{-1}$.
Shoots of all seagrass species shared a fraction of the ${ }^{13} \mathrm{C}$ and ${ }^{15} \mathrm{~N}$ incorporated with neighbouring ramets over the experimental period (i.e. 4 d, Figs $3 \& 4$ ). The translocation of resources within the clones described rather similar spatial patterns across species (Figs 3 \& 4). Zostera noltii and Cymodocea sp. tended to transport most of the ${ }^{13} \mathrm{C}$ and ${ }^{15} \mathrm{~N}$ to ramets placed between the incubated shoot and the apex of the horizontal rhizome, with all the ramets in-between receiving similar amounts of translocated resources, particularly ${ }^{15} \mathrm{~N}$ (Figs 3 \& 4). Halophila stipulacea also transported most of the ${ }^{15} \mathrm{~N}$ exported to ramets placed in-between the incubated shoot and the rhizome apex (Fig. 4), but this trend was not observed for translocation of carbon within $H$. stipulacea clones, probably because of the

Table 4. Natural abundance of ${ }^{13} \mathrm{C}$ and ${ }^{15} \mathrm{~N}$ ( $\delta$ values) in seagrass leaves. Average $\pm \mathrm{SE}$ estimates are provided

\begin{tabular}{|lrr|}
\hline Species & \multicolumn{2}{c|}{ Natural isotopic abundance } \\
& \multicolumn{1}{c}{$\delta^{13} \mathrm{C}$} & \multicolumn{1}{c|}{$\delta^{15} \mathrm{~N}$} \\
\hline Cymodocea nodosa & $-11.71 \pm 0.08$ & $1.51 \pm 0.16$ \\
Cymodocea serrulata & $-8.62 \pm 0.12$ & $7.88 \pm 0.98$ \\
Halophila stipulacea & $-6.99 \pm 0.18$ & $2.25 \pm 0.73$ \\
Halodule uninervis & $-6.69 \pm 0.17$ & $3.31 \pm 0.33$ \\
Posidonia oceanica & $-12.72 \pm 0.14$ & $4.58 \pm 0.24$ \\
Thalassodendron ciliatum & $-8.99 \pm 0.20$ & $5.9 \pm 0.53$ \\
Thalassia hemprichii & $-4.81 \pm 0.19$ & $8.37 \pm 0.94$ \\
Zostera noltii & $-11.36 \pm 0.24$ & $9.22 \pm 0.90$ \\
\hline
\end{tabular}




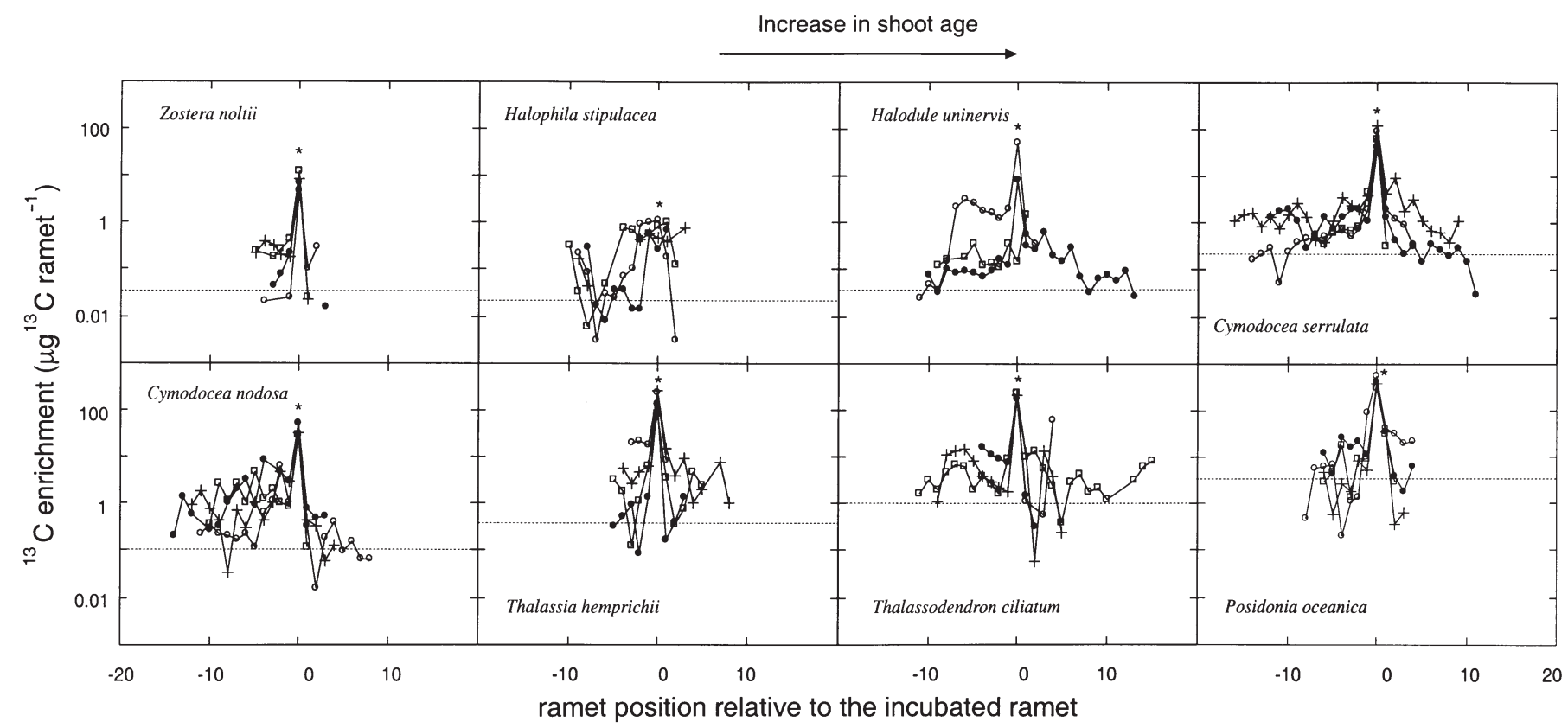

Fig. 3. Net increase of ${ }^{13} \mathrm{C}$ in the leaves, rhizome, and roots of ramets connected to the incubated ramet, $4 \mathrm{~d}$ after the incubation was conducted. The symbols used in each plot show the distribution of the isotope along the different experimental rhizomes of the same species. The position of the ramet incubated is indicated $\left(^{*}\right)$ for all species. Dashed lines indicate the amount of isotope in ramets of the different species under natural conditions

low isotopic enrichment achieved in these ramets. Conversely, translocation of resources along Thalassia hemprichii, Thalassodendron ciliatum and Posidonia oceanica rhizomes occurred more symmetrically to- wards both younger and older ramets (Figs 3 \& 4). Moreover, the translocation of resources to ramets of $T$. hemprichii, T. ciliatum and P. oceanica declined with distance from the source ramet along the rhizome.

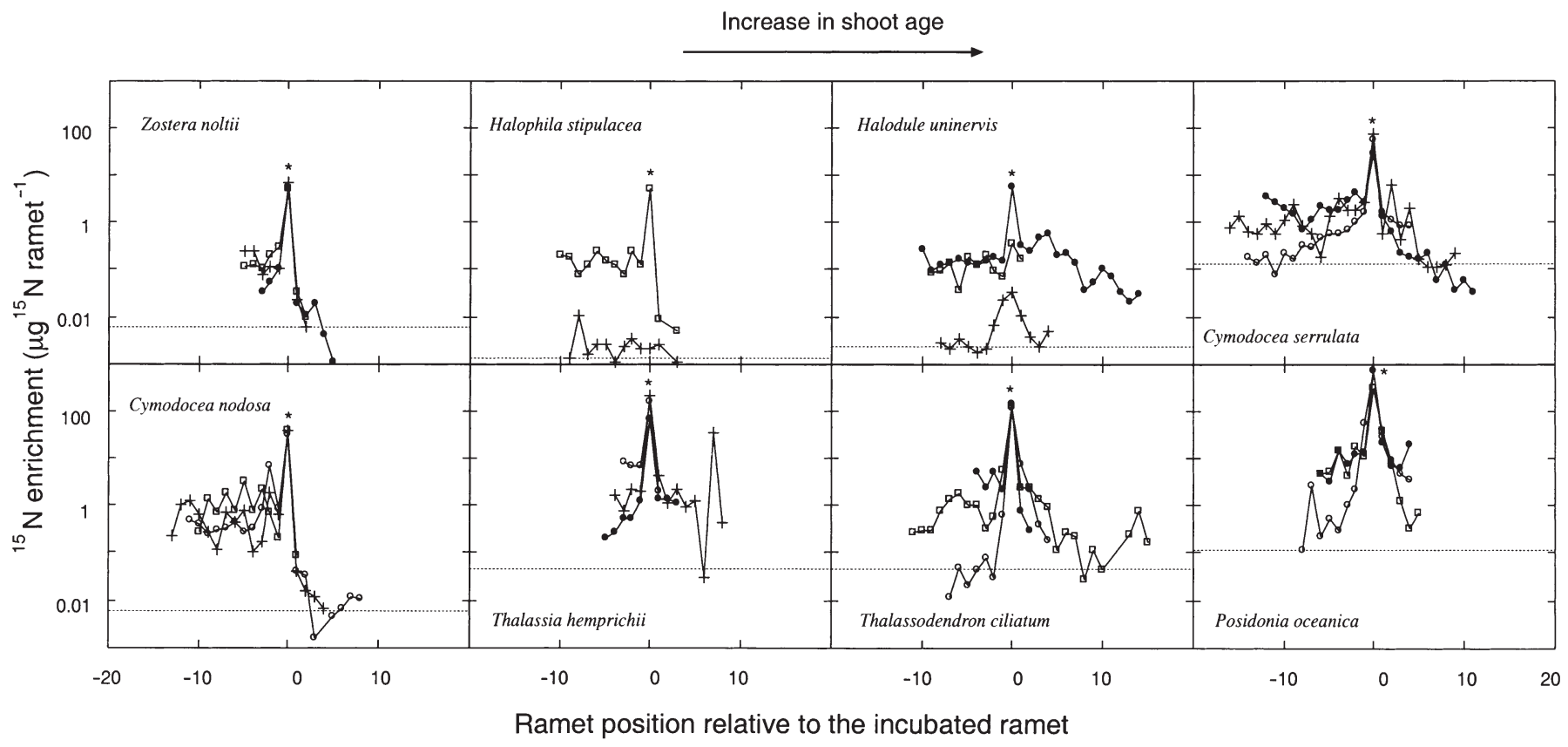

Fig. 4. Net increase of ${ }^{15} \mathrm{~N}$ in the leaves, rhizome, and roots of ramets connected to the incubated ramet, $4 \mathrm{~d}$ after the incubation was conducted. Detail as in Fig. 3 

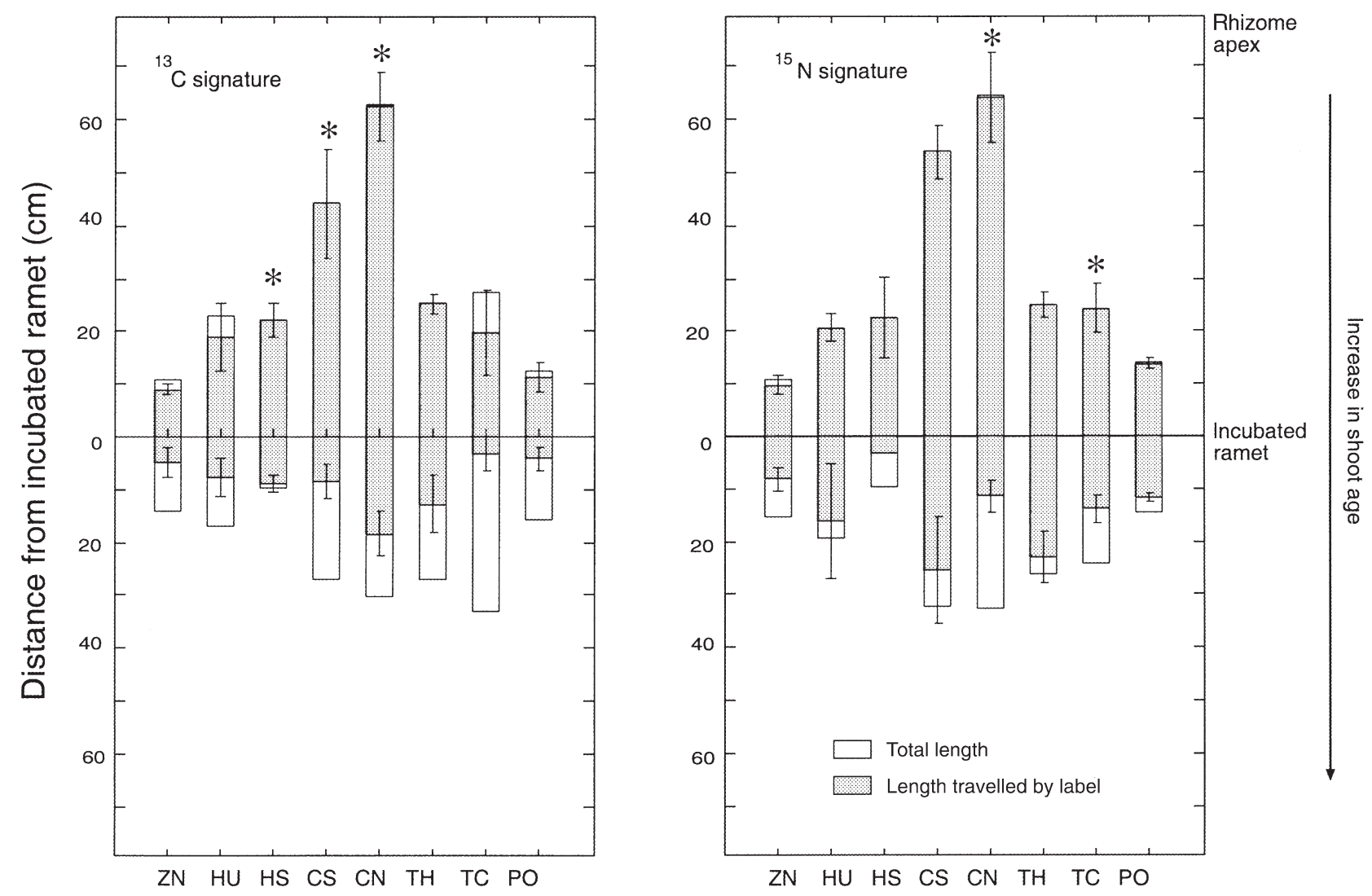

Fig. 5. Maximal distances travelled by ${ }^{13} \mathrm{C}$ and ${ }^{15} \mathrm{~N}$ within rhizomes of Cymodocea nodosa (CN), Cymodocea serrulata (CS), Halophila stipulacea (HS), Halodule uninervis (HU), Posidonia oceanica (PO), Thalassodendron cliatum (TC), Thalassia hemprichii (TH), and Zostera noltii (ZN) towards rhizome apices and towards the older parts of the clone (shaded bars). The length of the experimental rhizomes is indicated by open bars. Standard errors of the maximal distance reached by the isotopes are drawn.

*Species where asymmetric transport of isotopes was statistically significant (paired $t$-test, $\mathrm{p}<0.05$ )

The spatial scale of resource transport within seagrass clones varied among the species investigated (Fig. 5). ${ }^{13} \mathrm{C}$ was translocated along the rhizomes examined to maximum distances ranging from $4.0 \mathrm{~cm}$ (Halophila stipulacea) to $62.5 \mathrm{~cm}$ (Cymodocea nodosa) in $4 \mathrm{~d}$. Similarly, ${ }^{15} \mathrm{~N}$ was exported at maximum distances varying between $9.7 \mathrm{~cm}$ (Zostera noltii) and $64.3 \mathrm{~cm}$ (C. nodosa) from the source ramet in $4 \mathrm{~d}$. The ${ }^{15} \mathrm{~N}$ translocated reached the rhizome apex in all plants, except one rhizome of $H$. stipulacea and one of Thalassodendron ciliatum (Figs $4 \& 5$ ), whereas ${ }^{13} \mathrm{C}$ only reached the rhizome apices of all experimental rhizomes of C. serrulata, C. nodosa and Thalassia hemprichii (Figs 3 \& 5). Resources translocated from the source ramet provided ${ }^{13} \mathrm{C}$ and ${ }^{15} \mathrm{~N}$ to a minimum of 5 ramets (P. oceanica, Figs $3 \& 4$ ) and to a maximum of 21 ramets ( $C$. serrulata, Figs $3 \& 4$ ). Resource sharing between seagrass ramets was significantly (Wilcoxon's signed-ranks test, $\mathrm{p}<0.05$ ) asymmetric when comparing the average distances of tracer movement towards rhizome apex and towards the inner part of the clone across the species studied. Seagrass species allocated, on average, the resources translocated to their modules differently. Most seagrasses allocated most of the ${ }^{13} \mathrm{C}$ and ${ }^{15} \mathrm{~N}$ exported to below-ground modules (i.e. rhizomes and roots, Fig. 6). However, leaves of neighbouring ramets in $H$. stipulacea, Halodule uninervis and C. serrulata were the major sinks for the exported ${ }^{15} \mathrm{~N}$ (Fig. 6). Similarly, most of the exported ${ }^{13} \mathrm{C}$ fated in the leaves of neighbours in $H$. stipulacea (Fig. 6). The largest fraction of the carbon and nitrogen allocated to seagrass rhizomes, however, was recovered in notgrowing rhizome material. The C:N ratio of exported tracers was not significantly different (regression analysis, slope $=1 ; R^{2}=0.82, n=23, p<0.00001$ ) from that of tracers incorporated by the incubated seagrass shoots. Seagrass translocation, therefore, did not favour transport of one resource versus the other.

The incubated ramets shared, in $4 \mathrm{~d}$, between 0.37 and $390 \mu \mathrm{g}^{13} \mathrm{C}$ and between 0.02 and $178 \mu \mathrm{g}^{15} \mathrm{~N}$ of the isotopes incorporated with their neighbours. Therefore, developed seagrass ramets were able to share 

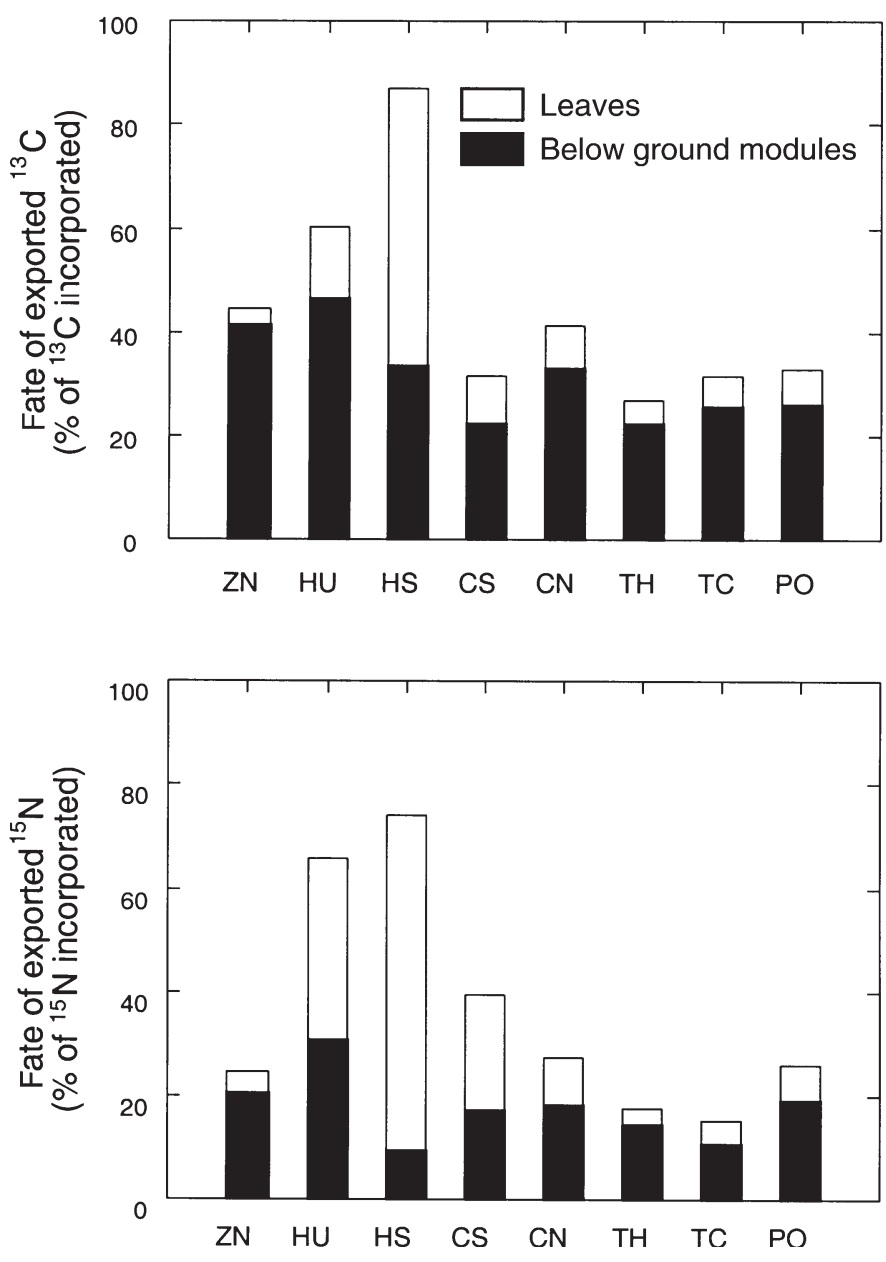

Fig. 6. Allocation of the ${ }^{13} \mathrm{C}$ (upper panel) and ${ }^{15} \mathrm{~N}$ (lower panel) exported to the leaves (open bars) and below-ground modules (i.e. rhizomes and roots, solid bars) of neighbour ramets in the studied seagrass species. Species codes are the same as in Fig. 5

with their neighbours between $27.1 \%$ (Thalassia hemprichii) and $80.6 \%$ (Halophila stipulacea) of the total ${ }^{13} \mathrm{C}$ incorporated, and between $15.5 \%$ (Thalassodendron ciliatum) and $72.6 \%$ (H. stipulacea) of the ${ }^{15} \mathrm{~N}$ taken up, in 4 d (Fig. 6).

\section{DISCUSSION}

The results presented demonstrate that an important fraction of the carbon and nitrogen incorporated by seagrass leaves from the water column is mobilised, often to considerable distances, to other parts of the clone within short periods of time. Hence, they conclusively demonstrate physiological integration between seagrass ramets. Moreover, the finding that nitrogen acquired by leaves is mobilised within the clone confirms that seagrass leaves may play an important role in seagrass nutrient acquisition, as previously observed in other seagrass species (Zostera marina, Izumi \& Hattori 1982, Pedersen \& Borum 1992; Phylospadix torreyi, Terrados \& Williams 1997; Thalassia testudinum, Lee \& Dunton 1999).

Seagrass resource translocation tends to proceed, in most of the rhizomes examined, towards the rhizome apices, which represent the expanding edges of the clones (Fig. 5). The asymmetrical resource mobilisation inside the clones reveals an important role of resource translocation in supporting seagrass clonal growth. The dependence of the expansion of the clone on the resources taken up by developed seagrass ramets observed during this study agrees with the results of previous experiments conducted in Cymodocea nodosa (Terrados et al. 1997b), and with studies of clonal plants on land (e.g. Hertnett \& Bazzaz 1983, Alpert 1991). Similarly, the strong demand for nutrients of young developing ramets is consistent with results also described for C. nodosa (Duarte \& SandJensen 1996), and supports the authors' contention that internal nutrient transport within clones of this species should be mostly directed towards the rhizome apex. A preference of acropetal translocation of assimilates has also been described in terrestrial clonal plants such are Saxifraga sarmentosa (Qureshi \& Spanner 1973), Agave deserti (Tissue \& Nobel 1990), and Fragaria chiloensis (Alpert 1991). The degree of asymmetry in resource translocation in terrestrial clones, however, also varies across species.

Our results also indicate that physiological integration within seagrass clones is maintained over distances ranging from, at least, a few centimetres (Halophila stipulacea, Fig. 6) to more than $80 \mathrm{~cm}$ (Cymodocea nodosa, Fig. 5). These findings are consistent with inferences from experimental results on $C$. nodosa, where rhizome growth was found to be affected by the status of ramets at distances $>0.5 \mathrm{~m}$ away from the horizontal rhizome apex (Terrados et al. 1997b), and direct estimations of carbon translocation across $15 \mathrm{~cm}$ distance in Posidonia oceanica using radiocarbon (Libes \& Boudouresque 1987). The variability observed in the spatial scale of clonal integration among seagrass rhizomes implies that seagrass ramets may be physiologically integrated over long time scales. Considering the total distance of tracer translocation (Fig. 5) and the rate of horizontal expansion of seagrass rhizomes of these species (Table 2), we calculate seagrass clonal integration may be maintained between $1.6 \mathrm{~d}$ (H. stipulacea) and $5.4 \mathrm{yr}$ (Posidonia oceanica). These are minimum estimates, as it is possible that a longer incubation time would have increased the maximum translocation distance.

The net production during the incubations should be much larger than the amount of of ${ }^{13} \mathrm{C}$ taken up, 
because this isotope was added at tracer levels. Total (i.e. ${ }^{12} \mathrm{C}$ and ${ }^{13} \mathrm{C}$ ) net production can be calculated from knowledge of plant $\delta^{13} \mathrm{C}$ at the start and end of the incubation, plant mass, the length of the incubation period, and the incubated water volume, as reported in Mateo et al. (2001). These calculations yield estimates of net production during the incubations ranging between 0.3 and $1.1 \mathrm{mgC} \mathrm{gDW}^{-1} \mathrm{~h}^{-1}$ (or 0.02 and $0.09 \mathrm{mmolC} \mathrm{gDW}^{-1} \mathrm{~h}^{-1}$; Table 5), which are rather similar to the net seagrass production expected from seagrass maximum photosynthesis rate, respiration rate, and DOC release. Seagrass photosynthesis laboratory experiments indicate seagrass gross production to be, on average, $2.6 \mathrm{mg} \mathrm{C} \mathrm{g} \mathrm{DW}^{-1} \mathrm{~h}^{-1}$ (cf. Touchette \& Burkholder 2000). Available literature data indicate that about $57 \%$ of seagrass gross production is respired (Duarte \& Cebrián 1996), and that seagrass DOC release is, at most, $11 \%$ of the gross production (Penhale \& Smith 1977, Moriarty et al. 1986, Blaabjerg et al. 1998). Hence, laboratory experiments indicate net

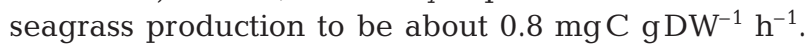
The use of the entire shoot, and the low light availability (down to $20 \%$ of incident light, see methods), during the experiments described here might also result into slightly lower net production rates than those expected from laboratory conditions.

Leaf nitrogen uptake rates quantified in situ during this study (Table 5) are similar to those expected for seagrasses growing at ambient ammonium concentrations between 1 and $5 \mu \mathrm{M} \mathrm{NH}_{4}$. According to the leaf ammonium uptake kinetics described for several seagrass species (cf. Touchette \& Burkholder 2000), seagrass leaves should incorporate nitrogen at rates ranging between 0.5 and $14.4 \mu \mathrm{molN} \mathrm{gDW}^{-1} \mathrm{~h}^{-1}$ when ambient ammonium concentration is $1 \mu \mathrm{M}$, and between 2.0 and $86.7 \mu \mathrm{mol} \mathrm{N} \mathrm{g} \mathrm{DW}{ }^{-1} \mathrm{~h}^{-1}$ when ambient ammonium concentration is $5 \mu \mathrm{M}\left\{V_{\text {ambient }}=\left(V_{\max } \times\right.\right.$ $\left.\left[\mathrm{NH}_{4}\right]_{\text {ambient }}\right) /\left(K_{\mathrm{m}}+\left[\mathrm{NH}_{4}\right]_{\text {ambient }}\right)$, where $V_{\text {ambient }}$ is the $\mathrm{N}$ uptake rate at ambient $\mathrm{N}$ concentration, $\left[\mathrm{NH}_{4}\right]_{\text {ambient }}$ is the ambient water column $\mathrm{NH}_{4}$ concentration, $V_{\max }$ is the maximum uptake rate and $K_{\mathrm{m}}$ is the half-saturation constant according to Michaelis-Menten kinetics in $\mathrm{N}$ absorption; e.g. Lee \& Dunton 1999\}. These results are consistent with the fact that most of the experimental seagrasses (i.e. Cymodocea serrulata, Halodule uninervis, Halophila ovalis, Thalassia hemprichii, Thalassodendron ciliatum, Zostera noltii) were growing in waters with natural $\mathrm{NH}_{4}$ concentrations of 1 to $5 \mu \mathrm{M}$.

Table 5. Net inorganic carbon and nitrogen uptake rates during the incubations, and the percentage of carbon and nitrogen requirements for leaf and rhizome growth supplied by translocation. These calculations assume that the resources recovered in leaves of neighbouring ramets and rhizome apices have been translocated over 1 or $4 \mathrm{~d}$ (i.e. the time scale of the study). Calculations made using shoot size, and carbon and nitrogen demand data compiled in Tables 2 \& 3

\begin{tabular}{|c|c|c|c|c|}
\hline \multirow[t]{3}{*}{ Species } & \multicolumn{2}{|c|}{ Resource uptake } & \multicolumn{2}{|c|}{$\begin{array}{l}\text { Percentage of resource demand } \\
\text { supplied by translocation }\end{array}$} \\
\hline & mmols resource & mg resource & Leaf growth $(\%)$ & Rhizome growth (\%) \\
\hline & $\mathrm{gDW}^{-1} \mathrm{~h}^{-1}$ & $\operatorname{shoot}^{-1} d^{-1 a}$ & $1-4 \mathrm{~d}$ & $1-4 \mathrm{~d}$ \\
\hline \multicolumn{5}{|l|}{ Carbon } \\
\hline Cymodocea nodosa & 0.047 & 0.80 & $2.20-8.79$ & $0.72-2.90$ \\
\hline Cymodocea serrulata & 0.045 & 1.21 & $1.35-5.39$ & $0.10-0.41$ \\
\hline Halodule uninervis & 0.092 & 0.25 & $1.11-4.45$ & $0.11-0.42$ \\
\hline Posidonia oceanica & 0.027 & 9.56 & $3.32-13.27$ & $0.66-2.65$ \\
\hline Thalassodendron ciliatum & 0.076 & 6.22 & $2.28-9.13$ & $1.24-4.95$ \\
\hline Thalassia hemprichii & 0.065 & 1.65 & $0.66-2.66$ & $4.49-17.97$ \\
\hline Zostera noltii & 0.075 & 0.09 & $0.37-1.48$ & $0.04-0.14$ \\
\hline Average & 0.061 & 2.82 & $1.61-6.45$ & $1.05-4.20$ \\
\hline SE & 0.009 & 1.48 & $0.42-1.71$ & $0.64-2.61$ \\
\hline \multicolumn{5}{|l|}{ Nitrogen } \\
\hline Cymodocea nodosa & 0.008 & 0.35 & $15.20-60.79$ & $7.45-29.80$ \\
\hline Cymodocea serrulata & 0.006 & 0.41 & $20.94-83.77$ & $4.13-16.52$ \\
\hline Halophila stipulacea & 0.004 & 0.03 & $9.14-36.57$ & $0.02-0.08$ \\
\hline Halodule uninervis & 0.003 & 0.02 & $3.72-14.89$ & $0.69-2.74$ \\
\hline Posidonia oceanica & 0.006 & 5.22 & $40.70-162.80$ & $18.93-75.72$ \\
\hline Thalassodendron ciliatum & 0.006 & 1.31 & $9.32-37.30$ & $19.08-76.32$ \\
\hline Thalassia hemprichii & 0.012 & 0.77 & $2.41-9.63$ & $36.50-145.99$ \\
\hline Zostera noltii & 0.017 & 0.05 & $3.11-12.43$ & $0.92-3.67$ \\
\hline Average & 0.008 & 1.02 & $13.06-52.27$ & $10.96-43.85$ \\
\hline $\mathrm{SE}$ & 0.001 & 0.66 & 4.91-19.66 & $4.92-19.71$ \\
\hline
\end{tabular}


Only for the Mediterranean seagrasses studied here (Posidonia oceanica and C. nodosa), which grew in waters with about 100 -fold less ammonium concentration than those growing on the Kenyan and Dutch coasts, could the enhanced ambient $\mathrm{NH}_{4}$ concentration have stimulated leaf $\mathrm{N}$ uptake rates during the incubations. However, the present lack of knowledge on the leaf $\mathrm{N}$ uptake kinetics for $P$. oceanica and C. nodosa prevents the comparison of the rates calculated here with those expected provided the growth conditions. The uptake rates of inorganic carbon and nitrogen (Table 5) indicate that these resources were incorporated by the leaves into the clones at a $\mathrm{C}: \mathrm{N}$ ratio, on average, of 12 , though it ranged between 0.6 ( $P$. oceanica) and 36 (in $H$. uninervis) during the incubation period. The uptake C:N ratio was lower than that quantified in plant tissues, suggesting that either nitrogen is easily lost, which appears unlikely, or the average nitrogen incorporation rate over the lifespan of seagrass tissues should be lower than that exhibited during the experiments.

Our results show that the translocation of recently incorporated resources by the leaves of 1 developed ramet may provide an important fraction of the resources needed for growth in other parts of the clone. Our results indicate that seagrass carbon translocation from 1 ramet should provide at least (i.e. if the carbon exported after $4 \mathrm{~d}$ was translocated at a uniform rate during this period) between 0.4 and $3.3 \%$ of the carbon needed to support the leaf growth of a single neighbouring shoot (Table 5). However, if the carbon taken up by a ramet is translocated during the first day after incorporation, 1 seagrass ramet would be able to provide between 1.5 and $13.3 \%$ of the carbon needed to support leaf growth to 1 neighbouring shoot (Table 5). One ramet should also be able to provide between $<0.1$ and $4.5 \%$ or between 0.4 and $17.9 \%$ of the carbon required for horizontal rhizome production, depending on the species and the time scale of carbon translocation considered (i.e. 4 or $1 \mathrm{~d}$, Table 5). Similarly, an individual, fully developed seagrass shoot may provide between 2.4 and $40.7 \%$ (if the nitrogen taken up by the shoot in $1 \mathrm{~d}$ is transferred to the neighbour in $4 \mathrm{~d}$ ) or between 9.6 and $162 \%$ (if the nitrogen taken up by the shoot in $1 \mathrm{~d}$ is transferred to the neighbour during the same day) of the nitrogen required by a single neighbouring shoot to grow (Table 5). The amount of nitrogen transferred from a single shoot to the rhizome apex may also be substantial, representing up to 36 or $145 \%$, depending on whether the translocation of the recovered nitrogen occurred over 4 or $1 \mathrm{~d}$, respectively, of the nitrogen required to support rhizome elongation (Table 5). The substantial contribution of translocated resources, particularly nitrogen, to the resource demand of neighbouring ramets demonstrates that translocation is an essential mechanism to support growth of seagrass ramets and clones.

There is evidence that the amount of translocated resources within seagrass clones, however, may vary in response to light availability. Zimmerman \& Alberte (1996) have demonstrated that translocation of radiocarbon from leaves to rhizomes and roots in Zostera marina is inhibited when roots became anoxic. Growth of seagrasses in low-light environments, therefore, should decline due, in addition to low carbon uptake rates, to low carbon supply to growing ramets by translocation. Moreover, the amount of nitrogen shared with neighbours may vary in response to ambient nutrient availability. Li et al. (1992) demonstrated that translocation supplied 50 or $11 \%$ of the nitrogen used for wheatgrass ramet growth depending on whether plants grew in environments with low or abundant external nitrogen.

Not all the resources incorporated into the clone, however, are invested in plant growth. The recovery of, on average, 28 and $16 \%$ of the carbon and nitrogen incorporated, respectively, into already developed seagrass rhizome strongly indicated that a substantial fraction of the resources translocated may be stored. The finding that most of the carbon is translocated into rhizomes agrees with the results from the experiments conducted in Posidonia oceanica by Libes \& Boudouresque (1987), and it is a general feature of high plants (Nobel 1991). This strategy should allow the maintenance of growth during periods of unfavourable growth conditions.

In conclusion, our results demonstrate that seagrasses are strongly physiologically integrated over length and time scales of up to $80 \mathrm{~cm}$ and $5.4 \mathrm{yr}$, respectively. Resource translocation is an important mechanism to provide the resources required by developing ramets and to support horizontal rhizome growth, and, therefore, it is essential in supporting seagrass clonal expansion. In addition, physiological integration and resource redistribution between seagrass ramets should allow the mobilisation of internal resources following small-scale disturbance, contributing therefore to the survival of the clone. The spatial pattern (direction and spatial scale), and the magnitude of resource sharing, however, vary greatly across species, suggesting a possible relationship between species size and translocation that deserves further attention. The species-specific differences in the extent of physiological integration and the capacity to redistribute resources within seagrass clones demonstrated here must, no doubt, have an important bearing on the clonal development of the species and, therefore, the role they play in the ecosystem. 
Acknowledgements. This study was funded by the grant no. IC18-CT96-0065 of the Commission of the European Communities within the framework of the INCO Programme. N.M. was supported by a post-doctoral grant from the Spanish Ministry of Education, M.A.M. by a post-doctoral grant from the European Commission (MAS2-ct-94-5022), and J.T. and E.G. by return contracts of the Spanish Ministry of Education. We are grateful to J. Kazungu for providing unpublished data, and to Jos van Soelen and Pauline Kamermans for laboratory assistance. We thank 2 anonymous reviewers for constructive comments on the manuscript. This is the contribution number 2852 of the NIOO Centre for Marine and Coastal Ecology Yerseke, The Netherlands.

\section{LITERATURE CITED}

Alpert P (1991) Nitrogen sharing among ramets increases clonal growth in Fragaria chilonensis. Ecology 72:69-80

Avice JC, Ourry A, Lemaire G, Boucaud J (1996) Nitrogen and carbon flows estimated by ${ }^{15} \mathrm{~N}$ and ${ }^{13} \mathrm{C}$ pulse-chase labeling during regrowth of alfalfa. Plant Physiol 112: 281-290

Bittaker HF, Iverson RL (1976) Thalassia testudinum productivity: A field comparison of measurement methods. Mar Biol 37:39-46

Blaabjerg V, Mouritsen KN, Finster K (1998) Diel cycles of sulphate reduction rates in sediments of a Zostera marina bed (Denmark). Aquat Microb Ecol 15:97-102

Bouton TW (1991) Stable carbon isotope ratios of natrual materials: I. Sample preparation and mass spectrometric analysis. In: Coleman DC, Fry B (eds) Carbon isotope techniques. Academic Press, San Diego, CA, p 115-171

Broecker WS (1974) Chemical oceanography. Harcourt Brace, London

Duarte CM (1990) Seagrass nutrient content. Mar Ecol Prog Ser 67:201-207

Duarte CM, Cebrián J (1996) The fate of marine autotrophic production. Limnol Oceanogr 41:1758-1766

Duarte CM, Sand-Jensen K (1996) Nutrient constraints on establishment from seed and on vegetative expansion of the Mediterranean seagrass Cymodocea nodosa. Aquat Bot 54:279-286

Duarte CM, Marbà N, Agawin N, Cebrian J and 8 others (1994) Reconstruction of seagrass dynamics: age determinations and associated tools for the seagrass ecologist. Mar Ecol Prog Ser 107:195-209

Evans J (1991) The effect of resource integration on fitness related traits in a clonal dune perennial, Hydrocotyle bonariensis. Oecologia 86:268-275

Evans J (1992) The effect of local resource availability and clonal integration on ramet functional morphology in Hydrocotyle bonariensis. Oecologia 89:265-276

Izumi H, Hattori A (1982) Growth and organic production of eelgrass (Zostera marina L.) in temperate waters of the Pacific coast of Japan. III. The kinetics of nitrogen uptake. Aquat Bot 12:245-256

Harrison PG (1978) Patterns of uptake and translocation of ${ }^{14} \mathrm{C}$ by Zostera americana den Hartog in the laboratory. Aquat Bot 5:93-97

Hertnett DC, Bazzaz FA (1983) Physiological integration among intraclonal ramets in Solidago canadensis. Ecology 64:779-788

Jónsdóttir IS, Callaghan TV (1990) Intraclonal translocation of ammonium and nitrate nitrogen in Carex bigelowii Torr. Ex Schwein. Using ${ }^{15} \mathrm{~N}$ and nitrate reductase assays. New Phytol 114:419-428
Lee KS, Dunton KH (1999) Inorganic nitrogen aquisition in the seagrass Thalassia testudinum: development of a wholeplant nitrogen budget. Limnol Oceanogr 44:1204-1215

Li YS, Redmann RE, van Kessel C (1992) Nitrogen budget and $15 \mathrm{~N}$ translocation in a perennial wheatgrass. Funct Ecol 6: 221-225

Libes M, Boudouresque CF (1987) Uptake and long-distance transport of carbon in the marine phanerogam Posidonia oceanica. Mar Ecol Prog Ser 38:177-186

Marbà N, Cebrián J, Enríquez S, Duarte CM (1996) Growth patterns of Western Mediterranean seagrasses: speciesspecific responses to seasonal forcing. Mar Ecol Prog Ser 133:203-215

Mateo MA, Renom P, Hemminga MA, Peene J (2001) Measurement of seagrass production using the ${ }^{13} \mathrm{C}$ stable isotope: a comparison with the classical $\mathrm{O}_{2}$ and ${ }^{14} \mathrm{C}$ methods. Mar Ecol Prog Ser 223:157-165

Moriarty DJW, Iverson RL, Pollard PC (1986) Exudation of organic carbon by the seagrass Halodule wrightii Aschers. and its effect on bacterial growth in the sediment. J Exp Mar Biol Ecol 96:115-126

Nobel PS (1991) Physicochemical and environmental plant physiology. Academic Press, San Diego

Pedersen MF, Borum J (1992) Nitrogen dynamics of eelgrass Zostera marina during a late summer period of high growth and low nutrient availability. Mar Ecol Prog Ser 80:65-73

Pedersen MF, Paling EI, Walker DI (1997) Nitrogen uptake and allocation in the seagrass Amphibolis antarctica. Aquat Bot 56:105-111

Penhale PA, Smith WO Jr (1977) Excretion of dissolved organic carbon by eelgrass (Zostera marina) and its epiphytes. Limnol Oceanogr 22:400-407

Perez M, Romero J, Duarte CM, Sand-Jensen K (1990) Nutrient limitation of Cymodocea nosoda growth: limiting nutrient, growth response, and influence of shoots characteristics. Mar Biol 109:129-133

Powell GVN, Kenworthy WJ, Fourqurean JW (1989) Experimental evidence for nutrient limitation of seagrass growth in a tropical estuary with restricted circulation. Bull Mar Sci 44:324-340

Qureshi FA, Spanner DC (1973) Movement of $\left[{ }^{14} \mathrm{C}\right]$ sucrose along the stolon of Saxifraga sarmentosa. Planta 110: 145-152

Short FT, Davis MW, Gibson RA, Zimmermann CF (1985) Evidence for phosphate limitation in carbonate sediments of the seagrass Syringodium filiforme. Estuar Coast Shelf Sci 20:419-430

Stapel J, Aarts TL, van Duynhoven BHM, de Groot JD, van den Hoogen PHW, Hemminga MA (1996) Nutrient uptake by leaves and roots of the seagrass Thalassia hemprichii in the Spermonde Archipelago, Indonesia. Mar Ecol Prog Ser 134:195-206

Terrados J, Williams SL (1997) Leaf versus root nitrogen uptake by the surfgrass (Phyllospadix torreyi S.Watson). Mar Ecol Prog Ser 149:267-277

Terrados J, Duarte CM, Kenworthy WJ (1997a) Experimental evidence for apical dominance in the seagrass Cymodocea nodosa. Mar Ecol Prog Ser 148:263-268

Terrados J, Duarte CM, Kenworthy WJ (1997b) Is the apical growth of Cymodocea nodosa dependent on clonal integration? Mar Ecol Prog Ser 158:103-110

Tissue DT, Nobel PS (1990) Carbon translocation between parents and ramets of a desert perennial. Ann Bot 66: 551-557

Tomasko DA, Dawes CJ (1989) Evidence for physiological integration between shaded and unshaded short shoots of Thalassia testudinum. Mar Ecol Prog Ser 54:299-305 
Touchette BW, Burkholder JM (2000) Review of nitrogen and phosphorus metabolism in seagrasses. J Exp Mar Biol Ecol 250:133-167

Vermaat JE, Verhagen FCA (1996) Seasonal variation in the intertidal seagrass Zostera noltii Hornem.: coupling demographic and physiological patterns. Aquat Bot 52:259-281

Editorial responsibility: Otto Kinne (Editor), Oldendorf/Luhe, Germany
Vermaat J, Agawin N, Duarte CM, Fortes MD, Marbà N, Uri J (1995) Meadow maintenance, growth and productivity of a mixed Philippine bed. Mar Ecol Prog Ser 124:215-225

Zimmerman RC, Alberte RS (1996) Effect of light/dark transition on carbon translocation in eelgrass Zostera marina seedlings. Mar Ecol Prog Ser 136:305-309

Submitted: January 9, 2001; Accepted: June 28, 2001 Proofs received from author(s): January 14, 2002 